\section{Criterion is a touchstone in study of early angiosperms}

\section{Xin Wang*}

State Key Laboratory of Palaeobiology and Stratigraphy, Nanjing Institute of Geology and Palaeontology and CAS Center for Excellence in Life and Paleoenvironment, Chinese Academy of Sciences, Nanjing 210008, China

ORCID: https://orcid.org/0000-0002-4053-5515
Received: 03 September, 2021

Accepted: 28 September, 2021

Published: 29 September, 2021

*Corresponding author: Xin Wang, State Key Laboratory of Palaeobiology and Stratigraphy, Nanjing Institute of Geology and Palaeontology and CAS Center for Excellence in Life and Paleoenvironment, Chinese Academy of Sciences, Nanjing 210008, China, E-mail: xinwang@nigpas.ac.cn

Keywords: Self-contradiction; Plant; Science; Nature Plants

Copyright: @ 2021 Wang X. This is an open-access article distributed under the terms of the Creative Commons Attribution License, which permits unrestricted use, distribution, and reproduction in any medium, provided the original author and source are credited.

https://www.peertechzpublications.com

Check for updates

\title{
Abstract
}

Herendeen et al. set up a criterion identifying fossil angiosperms while they named five examples of fossil angiosperms in the same paper. Their normal-appearing operation, however, is fundamentally flawed: their exemplar fossil angiosperms did not honor their own criterion. This operation confused their proponents as well as other botanical researchers, hindering healthy progress in study on the origin of angiosperms. Herendeen et al. are obligated to give a plausible explanation for their perplexing operation.

*Nature Plants has been informed of the problem in Herendeen et al. (2017). Nature Plants has refused to fix the problem due to reasons, according to the communication with Dr. Chris Surridge, an editor of Nature Plants.

\section{Background}

Early angiosperms have been a focus of controversy in botany mainly because different scholars adopt different undeclared self-accepted criteria identifying fossil angiosperms [1-23]. The situation started to improve as scholars started to set up criteria for fossil angiosperms. Wang [13] designated ovules enclosed before pollination as a criterion for fossil angiosperms, while Herendeen et al. [23] proposed another criterion including several different features for fossil angiosperms. Although different opinions are acceptable in science as long as the authors are self-consistent, Herendeen et al. [23] have gone beyond the tolerance scope of science: they failed to remain self-consistent.

\section{A Criterion for fossil angiosperms}

Herendeen et al. [23] assumed that fossil angiosperms in their terms can be inferred to have "unique angiosperm features" including "tetrasporangiate dithecate stamens with four pollen sacs arranged in two pairs, pollen grains with multiple apertures in a radially symmetrical or global arrangement, and carpels enclosing one or several bitegmic ovules with two integuments". If this criterion were accepted and applied in palaeobotany properly, it would definitely help to reduce controversy on the origin of angiosperms.

\section{Exemplar fossil angiosperms}

Herendeen et al. set up the following fossil taxa as good examples of fossil angiosperms, namely, Monetianthus, Canrightiopsis, Archaeanthus, Mauldinia, and Kajanthus [23]. It is noteworthy that all of these taxa were published by one or more members of Herendeen et al. These examples, if accepted and used properly, definitely would be helpful for study on early angiosperms, too.

\section{A wrangling between the criterion and examples}

Although, ideally, the above criterion and examples, both 
set up by the same group of authors in the same paper at the same time [23], should be coherent, the cruel reality, as shown in Table 1, is beyond everyone's imagination and tolerance: None of Monetianthus, Canrightiopsis, Archaeanthus, Mauldinia, and Kajanthus has all the features enumerated in the criterion proposed by Herendeen et al. [23].

In addition to the above self-contradiction, the criterion proposed by Herendeen et al. [23] appears to have been deserted by various later independent researchers [14,24-27] (including some of Herendeen et al. themselves [28,29]). Now it appears as if that Herendeen alone was the only single person who insists on the criterion proposed by Herendeen et al. [23] among all botanical researchers.

Although controversy is a routine and healthy existence in science, the self-inconsistency of Herendeen et al. [23] is astonishingly beyond the tolerance of anyone (probably including themselves, this explains why Friis et al. (part of Herendeen et al.) [28] have discarded the criterion).

\section{No wrangling between the criterion and examples?}

An explanation less embarrassing for Herendeen et al. is that they simply meant that their exemplar fossils "can be inferred with high confidence to have possessed all of the diagnostic features". To test whether this is true, Herendeen et al.'s own exemplar angiosperms constitute ideal testing samples. According to Herendeen et al. [23], Monetianthus, one of Herendeen et al.'s exemplar angiosperms, "can be inferred with high confidence to have possessed all of the diagnostic features". Friis et al. [30] did claim the existence of "two integuments" in Monetianthus. This echoing each other between Herendeen et al. [23] and Friis et al. [30] appears perfect in science and logics. However, anyone would be petrified when he puts Figure $5 \mathrm{f}$ of Friis et al. [30] and Figure $2 \mathrm{~h}$ (standard ovule with two integuments) of Herendeen et al. [23] side by side: Do they mean $1=2$ in botany? Such anti-science operation is not conceivable unless some errors or dishonesty occurred. It becomes obvious that the so-called "high confidence" of Herendeen et al. [23] is "zero confidence" in the reality.

\section{Conclusion}

Setting up both a criterion and examples that conflict each other at the same time by the same authors in the same paper is apparently unacceptable and absurd in science. It seems necessary for Herendeen et al. to give a plausible explanation

Table 1: None of their exemplar fossil angiosperms has all features enumerated in the criterion advanced by Herendeen et al.

\begin{tabular}{|c|c|c|c|c|c|}
\hline & Monetianthus & Canrightiopsis & Archaeanthus & Mauldinia & Kajanthus \\
\hline $\begin{array}{c}\text { Tetrasporangiate } \\
\text { stamen }\end{array}$ & No & No & No & No & Yes \\
\hline $\begin{array}{c}\text { Radial } \\
\text { multiaperturate } \\
\text { pollen grains }\end{array}$ & No & No & No & No & $\begin{array}{c}\text { Yes, } \\
\text { tricolpate }\end{array}$ \\
\hline Enclosed ovules & $?$ & Yes & Yes & Yes & Yes \\
\hline $\begin{array}{l}\text { Ovule with two } \\
\text { integuments }\end{array}$ & No & Yes & $?$ & No & No \\
\hline References & [30] & {$[31,32]$} & [5] & [33] & [34] \\
\hline
\end{tabular}

for their treatment. Otherwise this may become a permanent man-made abominable mystery in the history of science.

\section{Acknowledgement}

This research is supported by the Strategic Priority Research Program (B) of Chinese Academy of Sciences (XDB26000000) and National Natural Science Foundation of China (41688103, 91514302).

\section{References}

1. Krassilov VA (1977) The origin of angiosperms. Botanical Review 43: 143-176. Link: https://bit.ly/3A1Znex

2. Retallack G, Dilcher DL (1981) Early angiosperm reproduction: Prisca reynoldsii, gen. et sp. nov. from the mid-Cretaceous coastal deposits in Kansas, U.S.A. Paläontographica B 179: 103-107.

3. Retallack G, Dilcher DL (1981) Arguments for a glossopterid ancestry of angiosperms. Paleobiology 7: 54-67. Link: https://bit.ly/3zOTCkc

4. Dilcher D, Crepet W (1984) Historical Perspectives of Angiosperm Evolution: Introduction. Annals of the Missouri Botanical Garden 71: 348-350. Link: https://bit.ly/3zRkeAT

5. Dilcher DL, Crane PR (1984) Archaeanthus: An early angiosperm from the Cenomanian of the Western Interior of North America. Annals of the Missour Botanical Garden 71: 351-383. Link: https://bit.ly/3CUG4W3

6. Hickey LJ, Taylor DW (1996) Flowering plant origin, evolution \& phylogeny (eds D. W. Taylor \& L. J. Hickey)Ch. 8: 176-231. Link: https://bit.ly/2ZG5Dfn

7. Taylor DW (1991) Angiosperm ovule and carpels: their characters and polarities, distribution in basal clades, and structural evolution. Postilla 208 : 1-40. Link: https://bit.ly/3kNK307

8. Dilcher DL (2010) Plants in the Mesozoic Time: innovations, phylogeny, ecosystems (ed C.T. Gee)Ch. 6: 97-116.

9. Friis EM, Crane PR, Pedersen KR (2011) The early flowers and angiosperm evolution. Cambridge University Press, Cambridge.

10. Liu ZJ, Huang D, Cai C, Wang X (2018) The core eudicot boom registered in Myanmar amber. Scientific Reports 8: 16765. Link: https://go.nature.com/3zSK1IS

11. Liu ZJ, Wang X (2016) A perfect flower from the Jurassic of China. Hist Biol 28: 707-719. Link: https://bit.ly/2Y6zBsk

12. Wang $X$ (2017) A biased, misleading review on early angiosperms. Natura Science 9: 399-405. Link:.https://bit.ly/3ohnnYH

13. Wang X (2018) The Dawn Angiosperms. Springer, Cham, Switzerland. Link: https://bit.ly/3CTx9nU

14. Fu Q, Diez JB, Pole M, García Ávila M, Liu ZJ et al. (2018) An unexpected noncarpellate epigynous flower from the Jurassic of China. eLife 7: e38827. Link: https://bit.ly/3zX5zV6

15. Han G, Liu Z, Wang X (2017) A Dichocarpum-like angiosperm from the Early Cretaceous of China. Acta Geologica Sinica (English edition) 90: 1-8. Link: https://bit.ly/3oge7E8

16. Han G, Liu Z-J, Liu X-L, Mao L, Jacques FMB et al. (2016) A whole plant herbaceous angiosperm from the Middle Jurassic of China. Acta Geologica Sinica (English edition) 90: 19-29. Link: https://bit.ly/3ig5xSe

17. Sun G, Dilcher DL, Zheng S, Zhou Z (1998) In search of the first flower: a Jurassic angiosperm, Archaefructus, from Northeast China. Science 282 1692-1695. Link: https://bit.ly/3AV4Gh4 
18. Sun G, Ji Q, Dilcher DL, Zheng S, Nixon KC et al. (2002) Archaefructaceae, a new basal angiosperm family. Science 296: 899-904. Link: https://bit.ly/3oi5JUw

19. Leng Q, Friis EM (2003) Sinocarpus decussatus gen. et sp. nov., a new angiosperm with basally syncarpous fruits from the Yixian Formation of Northeast China. Plant Systematics and Evolution 241: 77-88. Link: https://bit.ly/2Wlwkoe

20. Leng Q, Friis EM (2006) Angiosperm leaves associated with Sinocarpus infructescences from the Yixian Formation (Mid-Early Cretaceous) of NE China. Plant Systematics and Evolution 262: 173-187. Link: https://bit.ly/3B5YG5f

21. Friis EM, Doyle JA, Endress PK, Leng Q (2003) Archaefructus -- angiosperm precursor or specialized early angiosperm? Trends Plant Sci 8: S369-S373. Link: https://bit.ly/3kPOxnc

22. Wang $X$ (2021) New observation on seed/ovule position in the fruit of Archaeanthus and its systematic implications. China Geology. doi: 10.31035/ cg2021026

23. Herendeen PS, Friis EM, Pedersen KR, Crane PR (2017) Palaeobotanical redux: revisiting the age of the angiosperms. Nature Plants 3: 17015. Link: https://go.nature.com/3ig5Ts2

24. Sokoloff DD, Remizowa MV, El ES, Rudall PJ, Bateman RM (2020) Supposed Jurassic angiosperms lack pentamery, an important angiosperm-specific feature. New Phytol 238: 420-426. Link: https://bit.ly/3mcKkK5

25. Coiro M, Doyle JA, Hilton J (2019) How deep is the conflict between molecular and fossil evidence on the age of angiosperms? New Phytol 233: 83-99. Link: https://bit.ly/3zSjhZh

26. Fu Q, Diez JB, Pole M, García-Ávila M, Wang X (2020) Nanjinganthus is an angiosperm, isn't it? China Geology 3: 359-361. Link: https://bit.ly/3kQqchm

27. Bateman RM (2020) Hunting the snark: the flawed search for mythica Jurassic angiosperms. Journal of Experimental Botany 71: 23-35. Link: https://bit.ly/3m5eQFD

28. Friis EM, Crane PR, Pedersen KR (2019) Hedyosmum-like fossils in the Early Cretaceous diversification of angiosperms. International Journal of Plant Sciences 180: 232-239. Link: https://bit.ly/2ZG7r89

29. Wang $X$ (2020) Groundless research published on the International Journal of Plant Sciences. Voice of the Publisher 6: 167-169. Link: https://bit.ly/3igJPNG

30. Friis EM, Pedersen KR, von Balthazar M, Grimm GW, Crane PR (2009) Monetianthus mirus gen. et sp. nov., a nymphaealean flower from the Early Cretaceous of Portugal. International Journal of Plant Sciences 170: 1086 1101. Link: https://bit.ly/3kShDCK

31. Friis EM, Crane PR, Pedersen KR, Stampanoni M, Marone F (2015) Exceptional preservation of tiny embryos documents seed dormancy in early angiosperms. Nature 528: 551-554. Link: https://go.nature.com/3AMvRuh

32. Friis EM, Crane PR, Pedersen KR, Stampanoni M, Marone F (2015) Canrightiopsis, a new Early Cretaceous fossil with Clavatipollenites-type pollen bridge the gap between extinct Canrightia and extant Chloranthaceae. Grana 54: 184-212. Link: https://bit.ly/3zOW2iM

33. Drinnan AN, Crane PR, Friis EM, Pedersen KR (1990) Lauraceous flowers from the Potomac Group (mid-Cretaceous) of eastern North America. Botanical Gazette 151: 370-384. Link: https://bit.ly/2XZWBsQ

34. Mendes MM, Grimm GW, Pais J, Friis EM (2014) Fossil Kajanthus lusitanicus gen. et sp. nov. from Portugal: floral evidence for Early Cretaceous Lardizabalaceae (Ranunculales, basal eudicot). Grana 53: 283-301. Link: https://bit.ly/3zSjTy3

\footnotetext{
Discover a bigger Impact and Visibility of your article publication with Peertechz Publications

Highlights

* Signatory publisher of ORCID

* Signatory Publisher of DORA (San Francisco Declaration on Research Assessment)

- Articles archived in worlds' renowned service providers such as Portico, CNKI, AGRIS, TDNet, Base (Bielefeld University Library), CrossRef, Scilit, J-Gate etc.

* Journals indexed in ICMJE, SHERPA/ROMEO, Google Scholar etc.

* OAI-PMH (Open Archives Initiative Protocol for Metadata Harvesting)

* Dedicated Editorial Board for every journa

* Accurate and rapid peer-review process

* Increased citations of published articles through promotions

* Reduced timeline for article publication

Submit your articles and experience a new surge in publication services (https://www.peertechz.com/submission).
}

Peertechz journals wishes everlasting success in your every endeavours. 